\title{
Matrix-GLA-Protein and Vascular Calcification: Can Diet Influence the Consequences of Matrix GLA Protein Inactivation? A Review
}

\author{
Mirzaie Masoud ${ }^{1}$, Josefina Kusnirova ${ }^{1}$, Johann Philipp Addicks ${ }^{2}$, Sheila Fatehpur ${ }^{1}$ \\ ${ }^{1}$ Department of Vascular Surgery, OWL, University clinics, Campus Lemgo, Germany \\ ${ }^{2}$ Institute of Neuroradiology, OWL, University clinics, Campus Lemgo, Germany \\ *Corresponding author: Prof. Masoud Mirzaie, MD; Head of the Department of Vascular Surgery OWL, University \\ clinics, Campus Lemgo, Germany; masoud.mirzaie@klinikum-lippe.de
}

Received 16 September 2021;

Accepted 25 September 2021;

Published 05 October 2021

\begin{abstract}
In vascular calcification, as a physiological process, intimal arterial calcification (IAC) associated with increased cardiovascular risk is distinguished from medial arterial calcification (MAC) localized mainly in the lamina elatica interna, which are not only based on different pathophysiological mechanisms. They also lead to different cardiovascular diseases.

While intimal arterial calcification involves inflammation and lipid accumulation, a calcification process similar to desmal ossification plays the main role in medial arterial calcification. In this context, the phenotype change of smooth muscle cells from muscular type to synthesizing form in the tunica media is considered to be of great importance, which puts the matrix GLA protein, mainly involved in bone metabolism, in the center of interest. The present review work elucidates the molecular biological basis of interaction of matrix GLA protein subunits in the pathogenesis of vascular calcifications and the influence of diet on the consequences of underactivation of matrix GLA protein.
\end{abstract}

Keywords: Matrix-GLA-protein, vascular calficification, vitamine $\mathrm{K}$, diet

\section{Introduction}

Vascular calcification (VCas) a physiological process occurs much earlier in high atherogenic status, such as chronic renal failure, diabetes [and oxidative stress, and is then associated with increased cardiovascular $(\mathrm{CV})$ mortality and morbidity ${ }^{[1-4]}$. This plays an important role especially in dialysis patients and patients under anticoagulant therapy. In this review work, we have described the influence of matrix GLA protein, fetuin A and their metabolites on vascular calcification and possible influence by diet.

\section{Discussion}

Previously, the phenotype change of smooth muscle cells from muscular type to synhetic form in the tunica media has been reported ${ }^{[5]}$. With the knowledge of smooth muscle cell differentiation to an osteoblastic phenotype as a crucial step for vascular calcification, the matrix GLA protein, which is mainly involved in bone metabolism, became the focus of interest ${ }^{[6,7]}$. In vascular calcification, intimal arterial calcification (IAC), previously associated with increased cardiovascular risk, has been distinguished from medial arterial calcification (MAC), which is mainly localized in the lamina elastica interna ${ }^{[8-11]}$ and also manifests differently radiographically. While intimal arterial calcification shows a patchy/patchy pattern on radiographs, medial arterial calcification causes linear or annular calcifications on radiographs ${ }^{[10,11]}$. Different pathophysiological mechanisms underlie both forms of calcification, which are not only triggered by different risk factors but may lead to different cardiovascular diseases ${ }^{[12]}$. Intimal arterial calcification is characterized by inflammation and lipid accumulation, whereas medial arterial calcification is an active calcification process similar to desmal ossification ${ }^{[12-15]}$. Recent observations on explanted carotid plaques also show two distinct plaque morphologies with evidence of desmal bone tissue in calcified plaques ${ }^{[16]}$. In larger patient collectives, a risk association between medial arterial calcification and advanced age, diabetes, and renal disease has been established ${ }^{[17-20]}$. An association of medial arterial calcification with arterial hypertension and hyperlipoproteinemia could not be verified ${ }^{[13-15]}$. Comorbidity analysis for intimal arterial calcification showed only an association with nicotinabuse and hyperlipoproteinemia ${ }^{[21]}$. The most potent natural inhibitor of calcification is considered to be Matrix Gla Protein (MGP); a vitamin K-dependent protein (VKDPs) secreted by both chondrocytes and smooth muscle cells [22-27]. 
One of the main mechanisms of action of MGP is based on direct inhibition of binding of bone morphogenetic protein-2 (BMP-2) expressed by endothelial foam cells of human atherosclerotic plaques to its receptor, as the main step to osteoblast differentiation of VSMCs within the arterial wall ${ }^{[28-31]}$.

Moreover, the matrix GLA protein binds to newly formed hydroxyapatite crystals through its high binding affinity ${ }^{[33]}$. It is this binding that initiates macrophages to phagocytose the newly formed MGP matrix protein ${ }^{[33]}$.

The binding and affinity of matrix GLA protein to BMP2 are directly dependent on the concentration of free calcium ions and carboxylation state of matrix GLA protein ${ }^{[34,35]}$.

The structural change of matrix GLA protein required for this binding is achieved by vitamin $\mathrm{K}$-dependent $\gamma$-carboxylation of Gla residues and phosphorylation of serine residues ${ }^{[36-40]}$.

Although deficiency of Mtrix GLA protein leads to significant changes in the structure and function of extracellular matrix Gla and marked diffuse vascular calcification, excessive expression of matrix GLA protein has been found in atherosclerotic plaques, the severity of which is directly associated with serum levels of matrix GLA protein ${ }^{[41-44]}$.

In contrast, significant low uncarboxylated MPG was found in patients with severe coronary artery disease (CAD) ${ }^{[28]}$. However, plasma levels of uncarboxylated MPG correlated with calcium deposition in abdominal aorta, common carotid, and coronary arteries ${ }^{[45]}$.

While no clear correlation between serum ucMGP level and CHD was found in female patients, this association was also absent in elderly patients with carotid intima-media thickness $\left(\right.$ cIMT) ${ }^{[46]}$.

However, in patients with stable CHD, low plasma ucMGP concentrations were associated with mortality ${ }^{[47]}$.

Carboxylated matrix GLA protein is of great importance in the prophylaxis of calciphylaxis. In patients requiring dialysis, a 0.1 decrease in serum cMGP was associated with a twofold risk of developing calciphylaxis ${ }^{[48]}$.

These patients have significantly higher plasma ucMGP levels compared with the general population ${ }^{[49-51]}$. In children requiring dialysis, the association between ucMGP and vascular calciphylaxis was absent ${ }^{[52]}$.

The association between different matrix GLA protein forms and cardiovascular disease and comorbidities is even more evident in female patients. Whereas previous studies have found an association between dephosphorylated uncarboxylated matrix Gla protein (dpucMGP) and arterial calcification in the general population, other research groups have demonstrated a clear correlation between dpucMGP levels and increases in aortic and femoro-popliteal pulse wave velocities ${ }^{[53-62]}$.

Only after menopause did serum dpucMGP levels correlate with carotid intima-media-thickness (cIMT) and endothelial dysfunction score ${ }^{[60]}$.

However, detailed data analysis showed that in female patients, only circulating dephosphorylated uncarboxylated matrix Gla protein (dpucMGP) and not uncarboxylated matrix Gla protein or (ucMGP) or dephoshorylated carboxylated matrix Gla protein dpcMGP correlated with the coronary artery calcium score (CAC) [62].

Plasma level-related mortality and fatal and nonfatal cardiovascular outcomes showed a significant correlation with dpucMGP plasma level in patients with advanced aortic stenosis, heart failure, type 2 diabetes mellitus, chronic peripheral arterial disease, and chronic renal failure, especially in patients with chronic renal failure and advanced aortic stenosis ${ }^{[63-71]}$.
Similarly, other studies showed an association between cardiovascular and all-cause mortality, heart failure, and relevant graft dysfunction after renal transplantation with plasma dpucMGP $^{[72,73]}$.

The retinal microcirculation is little known and little considered, but of great interest. The matrix GLA protein significantly regulates the structural integrity of the trabecular meshwork and retinal ganglion cells ${ }^{\text {[74-77] }}$.

The reduced retinal arteriolar diameter and arteriole-tovenule diameter ratio induced by doubling of plasma dp-ucMGP levels correlates directly with coronary artery disease, resulting mortality, and lacunar ${ }^{[78-82]}$.

Observational studies showed a beneficial effect of high vitamin $\mathrm{K}$ intake on cardiovascular morbidity ${ }^{[83]}$. However, a distinction must be made between vitamin K1 uptake, represented by plasma levels of circulating phylloquinone, and vitamin $\mathrm{K} 2$ uptake, represented by dephosphorylated uncarboxylated matrix Gla protein (dp-ucMGP) ${ }^{[84-87]}$.

Hepatic vitamin K-dependent proteins have been implicated as serine proteases in the coagulation system ${ }^{\text {[88-91] }}$.

As an extrahepatic vitamin K-dependent protein, osteocalcin regulates bone formation and mineralization ${ }^{[92]}$, with osteocalcin reflecting bone turnover ${ }^{[93]}$.

Total uncarboxylated MGP (t-ucMGP), consisting of phosphorylated MGP is sequestered at sites of arterial calcification [94].

With the increasing knowledge of vitamin-dependent matrix GLA proteins, vitamin $\mathrm{K}$ research has been shifted from blood coagulation to cardiovascular disease, osteoporosis, diabetes, and cancer, giving importance to nutrition in the context of key molecular biological functions of GLA ${ }^{[95]}$.

Hepatic vitamin $\mathrm{K}$ deficiency with consecutive coagulation disorders is a rarity compared with extrahepatic forms, especially in children, patients over 40 years of age, and chronic insufficiency, regardless of the stage of the disease ${ }^{[96-102]}$.

In previous case studies, antepartum administration of vitamin $\mathrm{K}$ to pregnant women reduced the incidence of neonatal hemorrhage ${ }^{[103]}$.

The originally used water-soluble vitamin K3 was replaced by intramuscular administration of vitamin $\mathrm{K} 1$ because of serious side effects including hematologic toxicities such as hemolytic anemia ${ }^{[104-107]}$.

Anticoagulant therapy with viatmin $\mathrm{K}$ antagonists, which is widely used worldwide, inevitably leads to suboptimal carboxylation of Gla proteins due to their mode of action, which has pronounced negative effects on the cardiovascular system ${ }^{[108-}$ 111]

An improved vitamin $\mathrm{K}$ status exerts a protective effect on vascular calcification, and led to vitamin $\mathrm{K} 1$ supplementaion. However, the results of such studies are highly controversial. While some studies, especially in female postmenopausal patients after vitamin K1 supplementation showed an unchanged atherosclerotic index in the carotid comm. artery, in some studies these were even decreased ${ }^{[112,113]}$.

The protective effect of vitamin $\mathrm{K} 1$ supplementation is particularly evident in dialysis patients. In such patients, both a reduction of dp-ucMGP plasma levels and reduced arterial stiffness could be achieved ${ }^{[114-118]}$.

A similar effect was achieved in patients with vitamin K2 (MK-7) supplementation. Dialysis patients in particular have a high prevalence of both vitamin $\mathrm{K}$ deficiency and cardiovascular disease ${ }^{[119,120]}$ 
In a recent study, vitamin D3 supplementation was found to reduce plasma dp-ucMGP levels ${ }^{[121]}$.

As in previous studies, this may suggest that vitamin D metabolism is closely related to that of vitamin $\mathrm{K}^{[122-125]}$.

The mutual interaction between the two vitamins also stems from the fact that binding of viatmin $D$ to a vitamin $D$ response element of the promoter of the MGP gene increases MGP expression two- to threefold ${ }^{[123,126]}$.

However, vitamin D can also lead to increased MGP secretion by directly stimulating the synthesis of vitamin Kdependent proteins, which in turn causes relative vitamin $\mathrm{K}$ deficiency ${ }^{[127]}$.

However, prolonged vitamin D supplementation even at low doses (up to $400 \mathrm{IU} /$ day) resulted in an increased risk of hypercalciuria, kidney stones, hypercalcemia, and vascular lesions [128-133].

The evaluation of several meta-analyses of randomized controlled trials also failed to prove a beneficial effect on musculoskeletal fractures by vitamin D supplementation ${ }^{[134-136]}$.

The interactions between lipid and bone metabolism and the regulation of vascular calcification by MPG is the basis of the developments of new diets to influence MPG ${ }^{[137,138]}$.

The effects of reduced carboxylated MGP (cMGP) and $\gamma$ glutamyl carboxylase (GGCX) in atherosclerotic aortic plaques in the presence of reduced expression of vitamin $\mathrm{K}$ epoxide reductase complex, subunit 1-gene (Vkor-gen) could be at least partially ameliorated by a high-fat diet ${ }^{[138-141]}$.

Another complex may also be affected by MPG. The fetuin-mineralization complexes known from animal studies, consisting of MGP (2\%), fetuin-A (80\%), and calcium and phosphorus ions (18\%) inhibit mineral growth, aggregation, and deposition ${ }^{[142-148]}$.

Fetuin-A itself may inhibit VSMC-related calcification via inhibition of apoptosis of VSMCs, promotion of clearance of apoptotic bodies released by VSMCs, and inhibition of intracellular mineralization of matrix vesicles of VSMCs ${ }^{[149-155]}$.

Several experimental studies have demonstrated the potent cytotoxic and procalcific Ca-phosphate crystals in the absence of fetuin-A ${ }^{[156,157]}$. A decrease in systemic fetuin-A increases systemic calciprotein particles and procalcification of calciprotein particles, thus promoting vascular calcification ${ }^{[158-162]}$.

The negative influence of low-protein diet on fetuin a derived from the animal experiments could only lead to an increase in vascular calcification with an increased calcium-phosphate load [150].

\section{Conclusion}

Vascular calcification represents a multifactorial process consisting of highly complex, interrelated pathophysiological pathways, the influence of diet on which requires further research. The long-term efficacy of new anticoagulants compared with vitamin antagonists can only be assessed after appropriate evaluation of prospective studies.

\section{List of abbreviations}

IAC: Intimal arterial calcification

MAC: Medial arterial calcification

VCas: Vascular calcification

CV: Cardiovascular

MGP: Matrix Gla Protein (MGP)

VKDP: Vitamin K-dependent protein
BMP-2 bone morphogenetic protein-2

VSMCs: Vascular smooth muscle cells

CAD: Coronary artery disease

cIMT: Carotid intima-media thickness

dpucMGP: Dephosphorylated uncarboxylated matrix Gla protein ucMGP: Uncarboxylated matrix Gla protein

t-ucMGP: Total uncarboxylated MGP

GGCX $: \gamma$-glutamyl carboxylase

\section{Conflicts of Interest}

There is no conflict of interest regarding the publication of this paper

\section{Funding Statement}

This research received no funding.

\section{Authors' contributions}

MM and SF have structured and written the paper. JK and JPA did the proofreading and fine-tuning of the paper. All authors read and approved the final manuscript.

\section{References}

[1] Ghosh S, Luo D, He W, et al. Diabetes and calcification: The potential role of anti-diabetic drugs on vascular calcification regression. Pharmacological Research, 2020; 158. doi.org/10.1016/j.phrs.2020.104861.

[2] Liakopoulos V, Roumeliotis S, Gorny X, Dounousi E, Mertens PR. Oxidative stress in hemodialysis patients: A review of the literature. Oxid Med Cell Longev, 2017: 3081856. doi: 10.1155/2017/3081856.

[3] Liakopoulos V, Roumeliotis S, Zarogiannis S, Eleftheriadis T, Mertens PR. Oxidative stress in hemodialysis: Causative mechanisms, clinical implications, and possible therapeutic interventions. Semin Dial, 2019; 58-71. doi.org/10.1111/sdi.12745.

[4] Nelson AJ, Raggi P, Wolf M, Gold AM, Chertow GM, Roe MT. Targeting Vascular Calcification in Chronic Kidney Disease, 2020; 5(4): doi.org/10.1016/j.jacbts.2020.02.002.

[5] Brinck U, Mirzaie M, Korabiowska M, Meyer T. Expression rate of vinculin isoforms in human aortocoronary saphenous vein grafts. Int J Cardiol, 1997; 125-132. doi.org/10.1016/S0167-5273(97)02919-7.

[6] Virchow R. Cellular pathology. As based upon physiological and pathological histology. Lecture XVIAtheromatous affection of arteries. Nutr Rev, 1989; 47:23-25. doi: 10.1111/j.1753-4887.1989.tb02747.x.

[7] Mori H, Torii S, Kutyna M, Sakamoto A, Finn AV, Virmani R, Coronary Artery Calcification and its Progression: What Does it Really Mean? JACC: Cardiovascular Imaging, 2018; 11(1): 127-142. doi.org/10.1016/j.jcmg.2017.10.012.

[8] Zwakenberg SR, de Jong PA, Hendriks EJ, et al. Intimal and medial calcification in relation to cardiovascular risk factors. PLoS ONE, 2020; 15(7): e0235228. doi:10.1371/journal.pone.0235228.

[9] Lanzer P, Boehm M, Sorribas V, et al. Medial vascular calcification revisited: review and perspectives. Eur 
Heart J, 2014; 14; 35(23): 1515-1525. doi: 10.1093/eurheartj/ehu163.

[10] Adar A, Onalan O, Keles Hb, Cakan F, Kokturk U. Relationship between Aortic Arch Calcification, Detected by Chest X-Ray, and Renal Resistive Index in Patients with Hypertension. Med Princ Pract, 2019; 28: 133-140. doi.org/10.1159/000495786.

[11] Koupenova M, Kehrel BE, Corkrey HA, Freedman JE. Thrombosis and platelets: an update. Europ Heart J, 2017; 38(11): 785-791. doi.org/10.1093/eurheartj/ehw550.

[12] Marshall AP, Lu0 W, Wang Xl, et al. Medial artery calcification increases neointimal hyperplasia after balloon injury. Sci Rep, 2019; 9, 8193. doi.org/10.1038/s41598-019-44668-4.

[13] Lin X, Zhu T, Xu F, et al. Plasma Exosomes Derived From Patients With End-Stage Renal Disease and Renal Transplant Recipients Have Different Effects on Vascular Calcification. Front Cell Dev Biol, 2021. doi.org/10.3389/fcell.2020.618228.

[14] Hendriks EJE, Beulens JWJ, Mali WPTM, et al. Breast Arterial Calcifications and Their Association With Incident Cardiovascular Disease and Diabetes. J Am Coll Cardiol, 2015; 65(8):859-60. doi: 10.1016/j.jacc.2014.12.015.

[15] Yoo JH, Kim JG, Chung K, et al. Vascular Calcification in Patients Undergoing Total Knee Arthroplasty: Frequency and Effects on the Surgery. Clin Orthop Surg, 2020; 12(2):171-177. doi.org/10.4055/cios19125.

[16] Mirzaie M, Guliyev Z, Schultz M, Schwartz P, Addicks JP, ShFatehpur S. Evidence of woven bone formation in carotid artery Plaques. J Cardiol Cardiovasc Med, 2021;6: 001-006. doi: 10.29328/journal.jccm.1001108.

[17] Hoek AG, Zwakenberg SR, Elders PJM, et al. An elevated ankle-brachial index is not a valid proxy for peripheral medial arterial calcification. Atherosclerosis, 2021; 323: 13-19. doi.org/10.1016/j.atherosclerosis.2021.03.010.

[18] Lee SJ, Lee IK, Jeon JH. Vascular Calcification-New Insights into Its Mechanism. Int. J. Mol. Sci. 2020, 21, 2685; doi:10.3390/ijms21082685.

[19] Wu X, Geng YJ, Chen Z, et al. Coron Artery Dis, 2019; 30(4):297-302. doi: 10.1097/MCA.0000000000000739.

[20] O’Neill WC, Han KH, Schneider TM, Hennigar RA. Prevalence of nonatheromatous lesions in peripheral arterial disease. Arterioscler Thromb Vasc Biol, 2015; 35(2):439-447. doi: 10.1161/ATVBAHA.114.304764.

[21] Madhavan MV, Tarigopula M, Mintz GS, Maehara A, Stone GW, Généreux P. Coronary artery calcification: pathogenesis and prognostic implications. J Am Coll Cardiol, 2014; 63(17):1703-1714. doi: 10.1016/j.jacc.2014.01.017.

[22] Wen L, Chen J, Duan L, LiS. Vitamin K-dependent proteins involved in bone and cardiovascular health (Review). Mol Med Rep, 2018; 18(1): 3-15. doi.org/10.3892/mmr.2018.8940.

[23] Lin X, Patil S, Gao YG, Qian A. The Bone Extracellular Matrix in Bone Formation and Regeneration. Front Pharmacol, 2020. doi.org/10.3389/fphar.2020.00757

[24] Zhang M, Ishikawa S, Inagawa $T$, et al. Influence of Mechanical Force on Bone Matrix Proteins in Ovariectomised Mice and Osteoblast-like MC3T3-E1
Cells. In Vivo, 2017; 31(1): 87-95. doi: 10.21873/invivo.11029.

[25] Bäck M, Aranyi T, Cancela ML, et al. Endogenous Calcification Inhibitors in the Prevention of Vascular Calcification: A Consensus Statement From the COST Action EuroSoftCalcNet. Front Cardiovasc, 2019. doi.org/10.3389/fcvm.2018.00196.

[26] Perrone E, Chen K, Ramos M, et al. A Novel MGP Gene Mutation Causing Keutel Syndrome in a Brazilian Patient. Mol Syndromol, 2018; 9:159-163. doi.org/10.1159/000488573.

[27] Cancel ML, Laizé V, Conceição N, Kempf H, Murshed M. Keutel Syndrome, a Review of 50 Years of Literature. Front Cell Dev Biol, 2021. /doi.org/10.3389/fcell.2021.642136.

[28] Roumeliotis S, Dounousi E, Salmas M, , Eleftheriadis T, Liakopoulos V. Vascular Calcification in Chronic Kidney Disease: The Role of Vitamin K- Dependent Matrix Gla Protein. Front Med, 2020. doi.org/10.3389/fmed.2020.00154.

[29] Robey PG, Boskey AL, Leikin S. Chapter 8 - The regulatory role of matrix proteins in mineralization of bone. Editor(s): David W. Dempster, Jane A. Cauley, Mary L. Bouxsein, Felicia Cosman, Marcus and Feldman's Osteoporosis (Fifth Edition), Academic Press, 2021: 165-187. doi.org/10.1016/B978-0-12-8130735.00008-3.

[30] Basic-Jukic N, Gulin M, Hudolin T, Kastelan Z. Expression of BMP-2 in Vascular Endothelial Cells of Recipient May Predict Delayed Graft Function After Renal Transplantation. Kidney Blood Press Res, 2016; 41:781-793. doi.org/10.1159/000450568.

[31] Leurs N, Martinand-Mari C, Ventéo S, Haitina T, Debiais-Thibaud M. Evolution of Matrix Gla and Bone Gla Protein Genes in Jawed Vertebrates. Front Genet, 2021. doi.org/10.3389/fgene.2021.620659.

[32] Wyatt CM, Drueke TB. Vascular calcification in chronic kidney disease: here to stay?

Nephro Digest Chronic Kidney Dis, 2017; 92(2): 276278. doi.org/10.1016/j.kint.2017.05.019.

[33] Wa Q, Liu Y, Huang Y, et al. miRNA-140 inhibits C3H10T1/2 mesenchymal stem cell proliferation by targeting CXCL12 during transforming growth factor$\beta 3$-induced chondrogenic differentiation. Mol Med Rep, 2017; 16(2): 1389-1394. doi.org/10.3892/mmr.2017.6720.

[34] Kuronuma K, Yokoi A, a Fukuoka T, et al. Matrix Gla protein maintains normal and malignant hematopoietic progenitor cells by interacting with bone morphogenetic protein-4, Heliyon, 2020; 6(4): e03743. doi.org/10.1016/j.heliyon.2020.e03743.

[35] Roumeliotis S, Dounousi E, Eleftheriadis T, Liakopoulos V. Association of the Inactive Circulating Matrix Gla Protein with Vitamin K Intake, Calcification, Mortality, and Cardiovascular Disease: A Review. Int. J Mol Sci, 2019; 20(3): 628. doi.org/10.3390/ijms20030628.

[36] Suzuki H, Tatei K, Ohshima N, Sato S, Izumi T. Extracellular matrix mineralization in the mouse osteoblast-like cell line MC3T3-E1 is regulated by actin cytoskeleton reorganization and non-protein molecules secreted from the cells themselves. BioRxiv, 2019. doi: https://doi.org/10.1101/551531. 
[37] Shea MK, L Booth SL. Vitamin K, Vascular Calcification, and Chronic Kidney Disease: Current Evidence and Unanswered Questions. Curr Dev Nutr, 2019; 3(9): nzz077. doi: 10.1093/cdn/nzz077.

[38] Zhu M, Zeng F, Cui Y, Liu X, Chen H. Expression of matrix Gla protein and bone morphogenetic protein 2 in renal papillary tissues in patients with calcium oxalate kidney stones. Journal of Central South University (Medical Sciences), 2017; (12): 277-283. doi: 10.11817/j.issn.1672-7347.2017.03.007.

[39] Mayer O, Seidlerová J, Bruthans J, et al. Desphosphouncarboxylated matrix Gla-protein is associated with mortality risk in patients with chronic stable vascular disease. Athreosclerosis, 2014; 235(1): 162-168. doi.org/10.1016/j.atherosclerosis.2014.04.027.

[40] Saad AAEA, Kenawy EM, Elashakr AM et al. Effect of vitamin K1 supplementation on matrix Gla protein level and vascular calcification in hemodialysis patients. Egypt J Intern Med, 2017; 29: 5-10. doi.org/10.4103/11107782.207779 .

[41] WeicX, Su Y, Li Q, Zheng Z, Hou P. Analysis of crucial genes, pathways and construction of the molecular regulatory networks in vascular smooth muscle cell calcification. Exp Thera Med, 2021, 21(6): 589. doi.org/10.3892/etm.2021.10021.

[42] Canet-Soulas E, Bessueille L, Mechtouff L, Magne D. The Elusive Origin of Atherosclerotic Plaque Calcification. Front Cell Dev, 2021. doi.org/10.3389/fcell.2021.622736.

[43] Zwakenberg SR, van der Schouw YT, Vermeer Cb, Pasterkamp G, den Ruijter HM, Beulens JWJ. Matrix Gla Protein, Plaque Stability, and Cardiovascular Events in Patients with Severe Atherosclerotic Disease. Cardiology, 2018; 141:32-36. doi.org/10.1159/000493006.

[44] Tesfamariam B. Involvement of Vitamin K-Dependent Proteins in Vascular Calcification. J Cardiovasc Pharmacol Ther, 2019; 24(4): 323-333. doi: 10.1177/1074248419838501.

[45] Rennenberg RJ, de Leeuw PW, Kessels AG, et al. Calcium scores and matrix Gla protein levels: association with vitamin K status. Eur J Clin Invest. 2010 Apr; 40(4): 344-349. doi: 10.1111/j.1365-2362.2010.02275.x.

[46] Dalmeijer GW, van der Schouw YT, Magdeleyns EJ, et al. Circulating species of matrix Gla protein and the risk of vascular calcification in healthy women. Int J Cardiol, 2013; 168(6): e168-70. doi: 10.1016/j.ijcard.2013.08.062.

[47] Parker BD, Schurgers LJ, Brandenburg VM, et al. The associations of fibroblast growth factor 23 and uncarboxylated matrix Gla protein with mortality in coronary artery disease: the Heart and Soul Study. Ann Intern Med, 2010; 152(10):640-648. doi: 10.1059/00034819-152-10-201005180-00004.

[48] Nigwekar SU, Bloch DB, Nazarian RM, et al. Vitamin K-Dependent Carboxylation of Matrix Gla Protein Influences the Risk of Calciphylaxis. J Am Soc Nephrol, 2017; 28(6): 1717-1722. doi: 10.1681/ASN.2016060651.

[49] Kurnatowska I, Grzelak P, Masajtis-Zagajewska A, et al. Plasma Desphospho-Uncarboxylated Matrix Gla Protein as a Marker of Kidney Damage and Cardiovascular Risk in Advanced Stage of Chronic Kidney Disease. Kidney
Blood Press Res, 2016; 41:231-239. doi.org/10.1159/000443426.

[50] Jaminon AMG, Dai L, Qureshi AR, et al. Matrix Gla protein is an independent predictor of both intimal and medial vascular calcification in chronic kidney disease. Sci Rep, 2020; 10, 6586. doi.org/10.1038/s41598-02063013-8.

[51] Jeannin AC, Salem JE, Massy Z, et al. Inactive matrix gla protein plasma levels are associated with peripheral neuropathy in Type 2 diabetes. PloS One, 2020; doi.org/10.1371/journal.pone.0229145.

[52] Ossareh S, Marghoob B, Bayat R. Relationship between Fetuin-A and vascular or valvular calcification in hemodialysis patients. J Clini Nephrol. 2019; 3: 001-011. DOI: 10.29328/journal.jcn.1001021.

[53] Delanaye P, Krzesinski JM, Warling X, et al. Dephosphorylated-uncarboxylated Matrix Gla protein concentration is predictive of vitamin $\mathrm{K}$ status and is correlated with vascular calcification in a cohort of BMC Nephrol, 2014; 15:145. doi: 10.1186/1471-2369-15-145.

[54] Griffin TP, Islam MN, Wall D, et al. Plasma dephosphorylated-uncarboxylated Matrix Gla-Protein (dp-ucMGP): reference intervals in Caucasian adults and diabetic kidney disease biomarker potential. Sci Rep, 2019; 9: 18452. doi.org/10.1038/s41598-019-54762-2.

[55] Ketteler M, Brandenburg VM. K-alcification Protection in Dialysis Patients: The Underestimated Phenomenon of Vitamin K Deficiency. JASN, 2017; 28(6): 1667-1668. doi.org/10.1681/ASN.2017020180.

[56] Roumeliotis S, Roumeliotis A, Panagoutsos S, et al. Matrix Gla protein T-138C polymorphism is associated with carotid intima media thickness and predicts mortality in patients with diabetic nephropathy. J Diabetes Complications, 2017; 31(10):1527-1532. doi: 10.1016/j.jdiacomp.2017.06.012.

[57] Ueland T, Gullestad L, Dahl CP, et al. Undercarboxylated matrix Gla protein is associated with indices of heart failure and mortality in symptomatic aortic stenosis. J Intern Med, 2010; 268(5): 483-492. doi: 10.1111/j.1365-2796.2010.02264.x.

[58] Shea MK, O'Donnell CJ, Vermeer C, et al. Circulating uncarboxylated matrix gla protein is associated with vitamin $\mathrm{K}$ nutritional status, but not coronary artery calcium, in older adults. J Nutr, 2011; 141: 1529-1534. doi: 10.3945/jn.111.139634.

[59] Pivin E, Ponte B, Pruijm M, et al. Inactive matrix Glaprotein is associated with arterial stiffness in an adult population-based study. Hypertension, 2015; 66:85-92. doi: 10.1161/HYPERTENSIONAHA.115.05177.

[60] Knapen MH, Braam LA, Drummen NE, et al. Menaquinone-7 supplementation improves arterial stiffness in healthy postmenopausal women. A doubleblind randomised clinical trial. Thromb Haemost, 2015; 113:1135-1144. doi: 10.1160/TH14-08-0675.

[61] Mayer O, Jr, Seidlerova J, Wohlfahrt P, et al. Desphospho-uncarboxylated matrix Gla protein is associated with increased aortic stiffness in a general population. J Hum Hypertens, 2016; 30(7):418-23. doi: 10.1038/jhh.2015.55.

[62] Aoun M, Makki M, Azar H, Matta H, Chelala DN. High dephosphorylated-uncarboxylated MGP in hemodialysis patients: Risk factors and response to vitamin K2, A pre- 
post intervention clinical trial. BMC Nephrol, 2017; 18:191. doi: 10.1186/s12882-017-0609-3.

[63] Ueland T, Gullestad L, Dahl CP, et al. Undercarboxylated matrix Gla protein is associated with indices of heart failure and mortality in symptomatic aortic stenosis. J Intern Med, 2010; 268:483-492. doi: 10.1111/j.1365-2796.2010.02264.x.

[64] Ueland T, Dahl CP, Gullestad L, et al. Circulating levels of non-phosphorylated undercarboxylated matrix Gla protein are associated with disease severity in patients with chronic heart failure. Clin Sci (Lond), 2011; 121:119-127. doi: 10.1042/CS20100589.

[65] Mayer O, Seidlerová J, Vaněk J, et al. The abnormal status of uncarboxylated matrix Gla protein species represents an additional mortality risk in heart failure patients with vascular disease. Int J Cardiol, 2016; 203: 916-922. doi: 10.1016/j.ijcard.2015.10.226

[66] Dalmeijer GW, van der Schouw YT, Magdeleyns EJ, et al. Matrix Gla protein species and risk of cardiovascular events in type 2 diabetic patients. Diabetes Care, 2013; 36:3766-3771. doi: 10.2337/dc13-0065.

[67] Mayer O, Seidlerová J, Bruthans J, et al. Desphosphouncarboxylated matrix Gla-protein is associated with mortality risk in patients with chronic stable vascular disease. Atherosclerosis, 2014; 235:162-168. doi: 10.1016/j.atherosclerosis.2014.04.027.

[68] Keyzer CA, Vermeer C, Joosten MM, et al. Vitamin K status and mortality after kidney transplantation: a cohort study. Am J Kidney Dis, 2015; 65:474-483. doi: 10.1053/j.ajkd.2014.09.014

[69] Liu YP, Gu YM, Thijs L, et al.. Inactive matrix Gla protein is causally related to adverse health outcomes: a Mendelian randomization study in a Flemish population. Hypertension, 2015; 65:463-470. doi: 10.1161/HYPERTENSIONAHA.114.04494.

[70] Riphagen IJ, Keyzer CA, Drummen NEA, et al. Prevalence and effects of functional vitamin $\mathrm{K}$ insufficiency: the PREVEND study. Nutrients. 2017; 9:e1334. doi: 10.3390/nu9121334.

[71] Van den Heuvel EG, van Schoor NM, Lips P, et al. Circulating uncarboxylated matrix Gla protein, a marker of vitamin $\mathrm{K}$ status, as a risk factor of cardiovascular disease. Maturitas, 2014; 77:137-141. doi: 10.1016/j.maturitas.2013.10.008.

[72] wie FF, Trenson S, Verhamme P, Vermeer C, Staessen JA. Vitamin K-Dependent Matrix Gla Protein as Multifaceted Protector of Vascular and Tissue Integrity. Hypertension, 2019; 73(6): 1160-1169. doi: 10.1161/HYPERTENSIONAHA.119.12412.

[73] Castiglione V, Pottel H, Lieske JC, et al. Evaluation of inactive Matrix-Gla-Protein (MGP) as a biomarker for incident and recurrent kidney stones. J Nephrol, 2020; 33(1): 101-107. soi: 10.1007/s40620-019-00623-0.

[74] Bermudez JY, Webber HC, Brown B, Braun TA, Clark AF, Mao W. A Comparison of Gene Expression Profiles between Glucocorticoid Responder and Non-Responder Bovine Trabecular Meshwork Cells Using RNA Sequencing. PloSOne, 2017. doi.org/10.1371/journal.pone.0169671.

[75] Borrás T, Smith MH, Buie LK. A novel Mgp-Cre knockin mouse reveals an anticalcification/antistiffness candidate gene in the trabecular meshwork and peripapillary scleral region. Invest Ophthalmol Vis Sci, 2015; 56: 2203-2214. doi: 10.1167/iovs.15-16460.

[76] Brnic D, Martinovic D, Zivkovic PM, et al. Inactive matrix Gla protein is elevated in patients with inflammatory bowel disease. World J Gastroenterol, 2020; 26(32): 4866-4877. doi: 10.3748/wjg.v26.i32.4866.

[77] Asokan P, Mitra RN, Periasamy R, Han Z, Borrás T. A naturally fluorescent Mgp transgenic mouse for angiogenesis and glaucoma longitudinal studies. Invest Ophthalmol Vis Sci, 2018; 59:746-756. doi: 10.1167/iovs.17-22992.

[78] Patel G, Fury W, Yang H, et al. Molecular taxonomy of human ocular outflow tissues defined by single-cell transcriptomics. PNAS, 2020; 117(23): 12856-12867. doi.org/10.1073/pnas.2001896117.

[79] Zheng W, Li Q, Zhao C, Da Y, ZhangHL, Chen Z et al. Differentiation of Glial Cells From hiPSCs: Potential Applications in Neurological Diseases and Cell Replacement Therapy. Front Cell Neurosci, 2018. doi.org/10.3389/fncel.2018.00239.

[80] Abdolrahimzadeh S, Felli L, Piraino DC et al. Retinal microvascular abnormalities overlying choroidal nodules in neurofibromatosis type 1. BMC Ophthalmol, 2014; 14, 146. doi.org/10.1186/1471-2415-14-146.

[81] Yatsuya H, Folsom AR, Wong TY, Klein R, Klein BE, Sharrett AR; ARIC Study Investigators. Retinal microvascular abnormalities and risk of lacunar stroke: Atherosclerosis Risk in Communities Study. Stroke, 2010; 41:1349-1355. doi: 10.1161/STROKEAHA.110.580837.

[82] Lin F, Zhu P, Huang F et al. Aortic stiffness is associated with the central retinal arteriolar equivalent and retinal vascular fractal dimension in a population along the southeastern coast of China. Hypertens Res, 2015; 38: 342-348 (2015). https://doi.org/10.1038/hr.2015.11.

[83] Zwakenberg SR, Burgess S, Sluijs I, et al. Circulating phylloquinone, inactive Matrix Gla protein and coronary heart disease risk: A two-sample Mendelian Randomization study Clin Nutr, 2020; 39(4):1131-1136. doi: 10.1016/j.clnu.2019.04.024.

[84] Liu YP, Gu YM, Thijs L, et al. Inactive matrix Gla protein is causally related to adverse health outcomes: a Mendelian randomization study in a Flemish population. Hypertension, 2015; 65(2):463-70. doi: 10.1161/HYPERTENSIONAHA.114.04494.

Dalmeijer GW, van der Schouw YT, Magdeleyns EJ, et al. Circulating desphospho-uncarboxylated matrix $\gamma$ carboxyglutamate protein and the risk of coronary heart disease and stroke. J Thromb Haemost, 2014; 12(7):1028-1034. doi: 10.1111/jth.12609.

[85] Zwakenberg SR, Remmelzwaal S, Beulens JWJ, et al. Circulating Phylloquinone Concentrations and Risk of Type 2 Diabetes: A Mendelian Randomization Study. Diabetes, 2019; 68(1): 220-225. doi: 10.2337/db18-0543.

[86] Shea MK, O'Donnell CJ, Vermeer C, et al. Circulating uncarboxylated matrix gla protein is associated with vitamin $\mathrm{K}$ nutritional status, but not coronary artery calcium, in older adults. J Nutr, 2011; 141(8):1529-1534. doi: 10.3945/jn.111.139634.

[87] Caluwé R, Verbeke F, De Vriese AS. Evaluation of vitamin $\mathrm{K}$ status and rationale for vitamin $\mathrm{K}$ 
supplementation in dialysis patients. Nephrol Dial Transplant, 2020; 35(1):23-33. doi: 10.1093/ndt/gfy373.

[88] Willems BA, Vermeer C, Reutelingsperger CP, Schurgers LJ. The realm of vitamin $\mathrm{K}$ dependent proteins: shifting from coagulation toward calcification. Mol Nutr Food Res. 2014; 58:1620-1635. doi: 10.1002/mnfr.201300743.

[89] Manolagas SC. Osteocalcin promotes bone mineralization but is not a hormone. PLoS Genet, 2020; 16(6): e1008714. doi.org/10.1371/journal.pgen.1008714.

[90] Levinger I, Brennan-Speranza TC, Zulli A, et al. Multifaceted interaction of bone, muscle, lifestyle interventions and metabolic and cardiovascular disease: role of osteocalcin. Osteoporos Int, 2017; 28:2265-2273. doi: 10.1007/s00198-017-3994-3.

[91] Geissler K, Jäger E, Barna A, et al. Molecular Basis and Clinical Application of Growth-Factor-Independent In Vitro Myeloid Colony Formation in Chronic Myelomonocytic Leukemia. Int J Mol Sci, 2020; 21(17): 6057. doi.org/10.3390/ijms21176057.

[92] Cranenburg ECM, Schurgers LJ. Vermeer C. Vitamin K: The coagulation vitamin that became omnipotent. Thromb Haemost, 2007; 98(01): 120-125. doi: 10.1160/TH07-04-0266.

[93] Alappan HR, Kaur G, Manzoor S, Navarrete J, O’Neill WC. Warfarin Accelerates Medial Arterial Calcification in Humans. Arterioscler Thromb Vasc Biol, 2020; 40:1413-1419.

doi.org/10.1161/ATVBAHA.119.313879.

[94] Cranenburg EC, Koos R, Schurgers LJ, et al. Characterisation and potential diagnostic value of circulating matrix Gla protein (MGP) species.Thromb Haemost, 2010; 104:811-822. doi: 10.1160/TH09-110786.

[95] Dahlberg S, Nilsson CU, Kander T, Schott U. Vitamin $\mathrm{K}$ : Nutrition, Metabolism and Current Evidence from Clinical Trials. Nutr Metab Open Acc, 2018: 101. doi:10.29011/NMOA-101/100001.

[96] Dauti F, Hjaltalin Jonsson M, Hillarp A, Bentzer P, Schott U. Perioperative changes in PIVKA-II. Scand J Clin Lab Invest, 2015; 75: 562-567. doi: 10.3109/00365513.2015.1058521.

[97] Dahlberg S, Nilsson CU, Kander T, Schott U. Detection of subclinical vitamin $\mathrm{K}$ deficiency in neurosurgery with PIVKA-II. Scand J Clin Lab Invest, 2017; 77: 267-274. doi: 10.1080/00365513.2017.1303190.

[98] Theuwissen E, Magdeleyns EJ, Braam LA, et al. Vitamin $\mathrm{K}$ status in healthy volunteers. Food Funct 5: 229-234. Food Funct, 2014; 5(2):229-234. doi: 10.1039/c3fo60464k.

[99] O'Connor EM, Grealy G, McCarthy J, et al. Effect of phylloquinone (vitamin K1) supplementation for 12 months on the indices of vitamin $\mathrm{K}$ status and bone health in adult patients with Crohn's disease. Br J Nutr, 2014; 11287): 1163-1174. doi: https://doi.org/10.1017/S0007114514001913.

[100] Kriegermeier A, Green R. Pediatric Cholestatic Liver Disease: Review of Bile Acid Metabolism and Discussion of Current and Emerging Therapies. Front Med, 2020: doi.org/10.3389/fmed.2020.00149.

[101] Kaesler N, Magdeleyns E, Herfs M, et al. Impaired vitamin $\mathrm{K}$ recycling in uremia is rescued by vitamin $\mathrm{K}$ supplementation. Kidney Int, 2014; 86: 286-293. doi: 10.1038/ki.2013.530.

[102] McCabe KM, Adams MA, Holden RM. Vitamin K status in chronic kidney disease. Nutrients, 2015; 5: 4390-4398. 10.3390/nu5114390.

[103] 103 Araki S, Shirahata A. Vitamin K Deficiency Bleeding in Infancy. Nutrients 2020, 12, 780; doi:10.3390/nu12030780.

[104] Ivanov DO. History of the study of hemorrhagic disease of newborns. Pediatrician (St. Petersburg), 2017: 8(4): 118-125. doi: 10.17816/PED84118-125.

[105] Obladen M. Early Neonatal Special Care Units and Their Scientific Achievements. Neonatology, 2012;102:89-97. doi: 10.1159/000336285.

[106] Dituri F, Buonocore G, Pietravalle A, et al. PIVKA-II plasma levels as markers of subclinical vitamin $\mathrm{K}$ deficiency in term infants. J Matern Fetal Neonatal Med, 2012; 25(9):1660-1663. doi: 10.3109/14767058.2012.657273.

[107] Ceratto, S, Savino F. Vitamin K deficiency bleeding in an apparently healthy newborn infant: the compelling need for evidence-based recommendation. Ital J Pediatr, 2019; 45, 30. doi.org/10.1186/s13052-019-0625-y.

[108] Marchili MR, Santoro E, Marchesi A, et al. Vitamin K deficiency: a case report and review of current guidelines. Ital J Pediatr, 2018; 44: 36. doi.org/10.1186/s13052-018-0474-0.

[109] McPherson C. Vitamin K Deficiency Bleeding: An Ounce of Prevention. Neonatal Network, 2018; 39(6). doi: 10.1891/0730-0832/11-T-630.

[110] Elango K, Javaid A, Khetarpal BK et al. The Effects of Warfarin and Direct Oral Anticoagulants on Systemic Vascular Calcification: A Review. Cells, 2021; 10, 773. doi.org/10.3390/cells10040773.

[111] Lin MC, Streja E, Soohoo M, Hanna M, Savoj J, Kalantar-Zadeh K, Lau W, L. Warfarin Use and Increased Mortality in End-Stage Renal Disease. Am J Nephrol, 2017; 46:249-256. doi: 10.1159/000481207.

[112] Asemi Z, RayganF, Bahmani F, et al. The effects of vitamin $\mathrm{D}, \mathrm{K}$ and calcium co-supplementation on carotid intima-media thickness and metabolic status in overweight type 2 diabetic patients with CHD. British Journal of Nutrition, 2016; 116: 286-293. doi:10.1017/S0007114516001847.

[113] Bartstra JW, Draaisma F, Zwakenberg SR et al. Six months vitamin $\mathrm{K}$ treatment does not affect systemic arterial calcification or bone mineral density in diabetes mellitus 2. Eur J Nutr, 2021; 60: 1691-1699. doi.org/10.1007/s00394-020-02412-z.

[114] Popa DS, Bigman, G, Rusu ME. The Role of Vitamin K in Humans: Implication in Aging and Age-Associated Diseases. Antioxidants, 2021; 10, 566. doi.org/10.3390/antiox10040566.

[115] Dai L, Li L, Erlandsson H, et al. (2021) Functional vitamin $\mathrm{K}$ insufficiency, vascular calcification and mortality in advanced chronic kidney disease: A cohort study. PLoS ONE, 2021; 16(2): e0247623. doi.org/10.1371/journal.pone.0247623.

[116] Nakanishi T, Kuragano T (eds): CKD-Associated Complications: Progress in the Last Half Century. Contrib Nephrol. Basel, Karger, 2019; 198: 62-72. doi: 10.1159/000496532). doi: 10.1159/000496532. 
[117] De Vriese AS, Caluwé R, Pyfferoen L, et al. Multicenter Randomized Controlled Trial of Vitamin K Antagonist Replacement by Rivaroxaban with or without Vitamin K2 in Hemodialysis Patients with Atrial Fibrillation: the Valkyrie Study. JASN, 2020; 31(1): 186-196. doi.org/10.1681/ASN.2019060579.

[118] Lindholt JS, Frandsen NE, Fredgart MH, et al. Effects of menaquinone-7 supplementation in patients with aortic valve calcification: study protocol for a randomised controlled trial. BMJ Open, 2018; 8:e022019. doi:10.1136/bmjopen-2018-022019.

[119] Saad AAEA, Kenawy EM, Elashakr AM et al. Effect of vitamin K1 supplementation on matrix Gla protein level and vascular calcification in hemodialysis patients. Egypt J Intern Med, 2017; 29: 5-10. doi.org/10.4103/11107782.207779 .

[120] Mott A, Bradley T, Wright $\mathrm{K}$ et al. Effect of vitamin K on bone mineral density and fractures in adults: an updated systematic review and meta-analysis of randomised controlled trials. Osteoporos Int, 2019; 30: 1543-1559. doi.org/10.1007/s00198-019.

[121] van Ballegooijen AJ, Beulens JWJ, Schurgers LJ, et al. Effect of 6-Month Vitamin D Supplementation on Plasma Matrix Gla Protein in Older Adults. Nutrients, 2019; 11(2): 231. doi: 10.3390/nu11020231.

[122] Hou YC, LU CH, Zheng CM, et al. Emerging Role of Vitamins $\mathrm{D}$ and $\mathrm{K}$ in Modulating Uremic Vascular Calcification: The Aspect of Passive Calcification. Nutrients, 2019; 11(1): 152. doi.org/10.3390/nu11010152.

[123] van Ballegooijen, AJ, Beulens J.WJ, Kieneker LM, et al. Combined low vitamin $\mathrm{D}$ and $\mathrm{K}$ status amplifies mortality risk: a prospective study. Eur J Nutr, 2021; 60: 1645-1654. doi.org/10.1007/s00394-020-02352-8.

[124] Florea A, Kooi ME, Mess W, Schurgers LJ, Bucerius J, Mottaghy FM. Effects of Combined Vitamin K2 and Vitamin D3 Supplementation on Na[18F]F PET/MRI in Patients with Carotid Artery Disease: The INTRICATE Rationale and Trial Design. Nutrients, 2021; 13(3): 994. doi.org/10.3390/nu13030994.

[125] Ambrożewicz E, Muszyńska M, Tokajuk G, Grynkiewicz G, Žarković N, E Skrzydlewska. Beneficial Effects of Vitamins K and D3 on Redox Balance of Human Osteoblasts Cultured with Hydroxyapatite-Based Biomaterials. Cells, 2019; 8(4): 325. doi.org/10.3390/cells8040325

[126] Van de Peppel J, van Leeuwen JPTM. Vitamin D and gene networks in human osteoblasts. Front Physiol. 2014;5:137. doi:10.3389/fphys.2014.00137.

[127] Cianciolo G, La Manna G, Della Bella E. Effect of Vitamin D Receptor Activator Therapy on Vitamin D Receptor and Osteocalcin Expression in Circulating Endothelial Progenitor Cells of Hemodialysis Patients. Blood Purif, 2013;35:187-195. doi.org/10.1159/000347102.

[128] Zittermann A, Ernst JB, Prokop S, et al. Effect of vitamin $\mathrm{d}$ on all-cause mortality in heart failure (evita): A 3-year randomized clinical trial with 4000 iu vitamin d daily. Eur Heart J, 2017;38: 2279-2286. doi: 10.1093/eurheartj/ehx235.

[129] Barbarawi M, Kheiri B, Zayed Y, et al. Vitamin D Supplementation and Cardiovascular Disease Risks in More Than 83000 Individuals in 21 Randomized
Clinical Trials: A Meta-analysis. JAMA Cardiol, 2019; 4(8): 765-776. doi:10.1001/jamacardio.2019.1870.

[130] Thiele I, Linseisen J, Meisinger C, et al. Associations between calcium and vitamin $\mathrm{d}$ supplement use as well as their serum concentrations and subclinical cardiovascular disease phenotypes. Atherosclerosis, 2015; 241:743-751. doi: 10.1016/j.atherosclerosis.2015.06.032.

[131] Challoumas D, Stavrou A, Pericleous A, Dimitrakakis G. Effects of combined vitamin d--calcium supplements on the cardiovascular system: Should we be cautious? Atherosclerosis. 2015;238:388-398. doi: 10.1016/j.atherosclerosis.2014.12.050.

[132] Zhang D, Li S, Zhang Z, et al. Urinary stone composition analysis and clinical characterization of 1520 patients in central China. Sci Rep, 2021; 11, 6467. doi.org/10.1038/s41598-021-85723-3.

[133] Kahwati LC, Weber RP, Pan H, et al. Vitamin d, calcium, or combined supplementation for the primary prevention of fractures in community-dwelling adults: Evidence report and systematic review for the us preventive services task force. JAMA, 2018; 319:1600 1612. doi: 10.1001/jama.2018.3185.

[134] Bolland MJ, Grey A, Avenell A. Effects of vitamin D supplementation on musculoskeletal health: A systematic review, meta-analysis, and trial sequential analysis. Lancet Diabetes Endocrinol, 2018; 6:847-858. doi:10.1016/S2213-8587(18)30265-1.

[135] Bjelakovic G, Gluud LL, Nikolova D, Whitfield K, Wetterslev J, Simonetti RG. Vitamin D supplementation for prevention of mortality in adults. Cochrane Database Syst Rev, 2014; 7:CD007470. doi: 10.1002/14651858.CD007470.pub3.

[136] Avenell A, Mak JC, O'Connell D. Vitamin D and vitamin $\mathrm{D}$ analogues for preventing fractures in postmenopausal women and older men. Cochrane Database Syst Rev, 2014; 4:CD000227. doi: 10.1002/14651858.CD000227.pub4.

[137] Lanham SA, Cagampang FR, Oreffo ROC. The influence of a high fat diet on bone and soft tissue formation in Matrix Gla Protein knockout mice. Sci Rep, 2018; 8: 3635. doi.org/10.1038/s41598-018-21650-0.

[138] Yao J, Guihard PJ, Blazquez-Medela AM et al. Matrix Gla protein regulates differentiation of endothelial cells derived from mouse embryonic stem cells. Angiogenesis, 2016; 19, 1-7. doi.org/10.1007/s10456-015-9484-3.

[139] Dahlberg S, Schott U. Vitamin K and its Role in Diabetic Vascular Complications and Low-Grade Inflammation. J Diabetes Treat, 2018; 138. doi: 10.29011/2574-7568. 000038 .

[140] Dai L, Li L, Erlandsson H, et al. Functional vitamin K insufficiency, vascular calcification and mortality in advanced chronic kidney disease: A cohort study. PloS One, 2021; 16(2): e0247623. doi: 10.1371/journal.pone.0247623. eCollection 2021.

[141] McCabe KM, Booth SL, Fu X, Ward E, Adams MA, Holden RM. . Vitamin K Metabolism in a Rat Model of Chronic Kidney Disease. Am J Nephrol, 2017; 45, 4-13. doi.org/10.1159/000451068.

[142] Wang C, Zang H, Zhou D. Bone morphogenetic protein2 exhibits therapeutic benefits for osteonecrosis of the femoral head through induction of cartilage and bone 
cells. Exp Ther Med, 2018; 15(5): 4298-4308. doi.org/10.3892/etm.2018.5941.

[143] Herrmann M, Babler A, Moshkova I, et al. Lumenal calcification and microvasculopathy in fetuin-A-deficient mice lead to multiple organ morbidity. PloS One, 2020; 15(2):e0228503. doi:10.1371/journal.pone.0228503.

[144] Lanham SA, Cagampang FR, Oreffo ROC. The influence of a high fat diet on bone and soft tissue formation in Matrix Gla Protein knockout mice. Sci Rep, 2018; 8: 3635. doi.org/10.1038/s41598-018-21650-0.

[145] Viegas CS, Cavaco S, Neves PL, Ferreira A, João A, Williamson MK, Price PA, Cancela ML and Simes DC: Gla-rich protein is a novel vitamin K-dependent protein present in serum that accumulates at sites of pathological calcifications. Am J Pathol. 175:2288-2298. 2009. doi.org/10.1161/ATVBAHA.114.304823.

[146] Surmann-Schmitt C, Dietz U, Kireva T, et al: Ucma, a novel secreted cartilage-specific protein with implications in osteogenesis. J Biol Chem, 2008; 11:7082-7893. doi: 2008. 10.1074/jbc.M702792200.

[147] Viegas CS, Rafael MS, Enriquez JL, et al: Gla-rich protein (GRP) acts as a calcification inhibitor in the human cardiovascular system. Arterioscler Thromb Vasc Biol, 2015; 35:399-408. doi: 10.1161/ATVBAHA.114.304823.

[148] Rafael MS, Cavaco S, Viegas CS, et al. Insights into the association of Gla-rich protein and osteoarthritis, novel splice variants and $\gamma$-carboxylation status. Mol Nutr Food Res. 58:1636-1646. 2014. doi:10.1002/mnfr.201300941.

[149] Yamada S, Tokumoto M, Tsuruya K, et al. Fetuin-A decrease induced by a low-protein diet enhances vascular calcification in uremic rats with hyperphosphatemia. Am J Physiol Renal Physiol, 2015; 309(8):744-754. doi: 10.1152/ajprenal.00017.2015

[150] Chen HY, Chiu YL, Hsu SP, Pai MF, Yang JY, Peng YS. Relationship between Fetuin A, Vascular Calcification and Fracture Risk in Dialysis Patients. PLoS One, 2016; 11(7): e0158789. doi: 10.1371/journal.pone.0158789.

[151] Bourebaba L, Marycz K. Pathophysiological Implication of Fetuin-A Glycoprotein in the Development of Metabolic Disorders: A Concise Review. J Clin Med, 2019; 8(12): 2033. doi.org/10.3390/jcm8122033.

[152] Kapustin AN, Chatrou ML, Drozdov I, et al. Vascular smooth muscle cell calcification is mediated by regulated exosome secretion. Circ Res, 2015; 116(8): 1312-23. doi: 10.1161/CIRCRESAHA.116.305012.

[153] Rudloff S, Janot M, Rodriguez S et al. Fetuin-A is a HIF target that safeguards tissue integrity during hypoxic stress. Nat Commun, 2021; 12: 549. doi.org/10.1038/s41467-020-20832-7.

[154] Cano-Megías M, Guisado-Vasco P, Bouarich H, et al. Coronary calcification as a predictor of cardiovascular mortality in advanced chronic kidney disease: a prospective long-term follow-up study. BMC Nephrol, 2019; 20: 188. doi.org/10.1186/s12882-019-1367-1.
[155] Luna-Luna M Criales-Vera Medina-Leyte D, et al. Bone Morphogenetic Protein-2 and Osteopontin Gene Expression in Epicardial Adipose Tissue from Patients with Coronary Artery Disease Is Associated with the Presence of Calcified Atherosclerotic Plaques. Diabetes Metab Syndr Obes, 2020; 13: 1943-1951. doi: 10.2147/DMSO.S253632.

[156] Cozzolino M, Galassi A, Ciceri P. Do we need new phosphate binders in dialysis? Clin Kidney J, 2021; 14(2): 474-475. doi.org/10.1093/ckj/sfaa246.

[157] Bostom A, Pasch A Madsen T, et al. Serum Calcification Propensity and Fetuin-A: Biomarkers of Cardiovascular Disease in Kidney Transplant Recipients. Am J Nephrol, 2018; 48(1): 21-31. doi: 10.1159/000491025.

[158] Uedono H, Mori K, Ochi A, et al. Effects of fetuin-Acontaining calciprotein particles on posttranslational modifications of fetuin-A in HepG2 cells. Sci Rep 2021; 11: 7486. doi.org/10.1038/s41598-021-86881-0.

[159] Cozzolino M, Ciceri P, Galassi A, et al. The Key Role of Phosphate on Vascular Calcification. Toxins (Basel), 2019; 11(4): 213. doi: 10.3390/toxins11040213.

[160] Koeppert S, Ghallab A, Peglow S, et al. Live Imaging of Calciprotein Particle Clearance and Receptor Mediated Uptake: Role of Calciprotein Monomers. Front. Cell Dev Biol, 2021. doi.org/10.3389/fcell.2021.633925.

[161] Bramania PK, Ruggajo P, Bramania R, et al. Prevalence of malnutrition inflammation complex syndrome among patients on maintenance haemodialysis at Muhimbili National Hospital in Tanzania: a cross-sectional study. BMC Nephrol, 2020; 21: 521. doi.org/10.1186/s12882020-02171-3.

[162] Kawate Y, Miyata H. The importance of nutritional intervention by dietitians for hyperphosphatemia in maintained hemodialysis patients. Ren Replace Ther, 2017; 3: 19. doi.org/10.1186/s41100-017-0095-x.

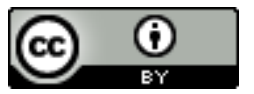

Open Access This article is licensed under a Creative Commons Attribution 4.0 International License, which permits use, sharing, adaptation, distribution and reproduction in any medium or format, as long as you give appropriate credit to the original author(s) and the source, provide a link to the Creative Commons license, and indicate if changes were made. The images or other third party material in this article are included in the article's Creative Commons license, unless indicated otherwise in a credit line to the material. If material is not included in the article's Creative Commons license and your intended use is not permitted by statutory regulation or exceeds the permitted use, you will need to obtain permission directly from the copyright holder. To view a copy of this license, visit https://creativecommons.org/licenses/by/4.0/.

(c) The Author(s) 2021 